\title{
Rapid Test for Determining the Intracellullar Rhodanese Activity of Various Bacteria
}

\author{
PETER A. VANDENBERGH, ROGER E. BAWDON, AND RICHARD S. BERK
}

Departments of Immunology and Microbiology, and Pathology, Wayne State University School of Medicine, Detroit, Michigan 48201

\begin{abstract}
A simple, reproducible technique with potential taxonomic application was developed for the rapid detection of rhodanese activity in gram-negative and gram-positive bacteria. The method requires suspension of the growth from three colonies in a solution of lysozyme and ethylenediaminetetraacetic acid for $60 \mathrm{~min}$. After cell lysis, the presence of rhodanese activity is determined colorimetrically by measuring the amount of thiocyanate formed from thiosulfate and potassium cyanide by use of ferric nitrate. By this technique, a survey of 411 bacterial strains revealed the presence of rhodanese in all test strains of Escherichia coli, Pseudomonas aeruginosa, Acinetobacter, Bordetella, Shigella, and Citrobacter. No activity was detected in Salmonella, Klebsiella, Enterobacter, Serratia, or Proteus species. Randomly selected strains which did not exhibit rhodanese activity were confirmed to be rhodanese-negative by assay of mechanically disrupted cells harvested from $500 \mathrm{ml}$ of growth medium.
\end{abstract}

Rhodanese, also known as thiosulfate:cyanide sulphurtransferase (E.C. 2.8.1.1), was originally described by Lang (4). The enzyme catalyzes the formation of thiocyanate from cyanide and thiosulfate according to the following equation: $\mathrm{S}_{2} \mathrm{O}_{3}{ }^{=}+\mathrm{CN}^{-} \rightarrow \mathrm{SCN}^{-}+\mathrm{SO}_{3}{ }^{2}$. Rhodanese was first isolated by Sörbo in 1953 in crystalline form from bovine liver (7). It has since been found in all mammalian tissues except blood and muscle, the highest being in the adrenals and liver. Various plant and microbial sources also demonstrate rhodanese activity. A comprehensive survey of many different organisms for the presence of rhodanese activity has been lacking, and it was initially thought that the enzyme is primarily restricted to various species of thiobacilli and photosynthetic bacteria (11). However, previous studies by Hall and Berk (1), and Schook and Berk (6), suggest that the activity is constitutively present and may be more widespread than previously suspected. Since intracellular rhodanese activity cannot be detected by conventional diagnostic techniques employing growing or resting cell suspensions (i.e., Analytical Products Inc.), a rapid screening technique was developed. This technique employed lysis of the cells in three picked colonies by ethylenediaminetetraacetic acid (EDTA)-lysozyme preparations and subsequent rhodanese assay of the lysed-cell supernatant. The accuracy of the results obtained by this type of cell lysis exhibited $100 \%$ correlation with the results obtained with mechanically disrupted broth-grown cells. Therefore, the following survey of mechanically lysed cells and EDTA-lysozyme lysed cells was undertaken to determine the degree of distribution of the enzyme in various bacteria in the hope that it may be of potential taxonomic and diagnostic significance.

\section{MATERIALS AND METHODS}

Bacterial strains and culture conditions. The bacterial strains used for this survey are listed in Tables 1 and 2. The sources of cultures of these strains are identified in Acknowledgments. The assay of intracellular rhodanese activity was performed by two different methods employing extracts obtained either by mechanical disruption of cells (cell-free extracts), using a French Press or by lysozyme-EDTA treatment. Cell-free extracts prepared from 61 organisms mechanically disrupted were initially assayed for rhodanese activity. The organisms used in this study were routinely cultured in $500 \mathrm{ml}$ of a peptone-Trypticase soy broth (BBL Microbiology Systems) on a shaker for 24 $\mathrm{h}$ at $35^{\circ} \mathrm{C}$. After $24 \mathrm{~h}$ of growth, these cells were harvested by centrifugation at $10,000 \times g$ for 30 $\min$ and washed twice with $0.85 \%$ saline. The washed cells were suspended in $25 \mathrm{ml}$ of 0.1 M tris(hydroxymethyl)aminomethane-hydrochloride buffer (pH 8.0) and disrupted three times with a French Press at $16,000 \mathrm{lb} / \mathrm{in}^{2}$.

A total of 411 organisms were screened by the second cellular disruption procedure. These organisms were routinely grown for $18 \mathrm{~h}$ at $35^{\circ} \mathrm{C}$ on trypticase soy agar plates containing $5 \%$ sheep's blood (BBL Microbiology Systems). Three colonies were removed from the plate with a sterile loop and standardized to a cell concentration of $1.5 \times 10^{4}$ cells per ml at $440 \mathrm{~nm}$. Lysozyme and potassium-EDTA (final concentrations, $0.5 \mathrm{mg} / \mathrm{ml}$ and $10 \mathrm{mM}$, respectively) were added to the test tube (2). The cells were incubated in this solution for $60 \mathrm{~min}$ at $25^{\circ} \mathrm{C}$, and cell mixtures were routinely monitored for release of nucleic acid at $260 \mathrm{~nm}$ to 
TABLE 1. Rhodanese activity in mechanically lysed cells of various bacteria ${ }^{\prime}$

\begin{tabular}{ccc}
\hline Organism & $\begin{array}{c}\text { Sp. act. } \\
\text { ( } \mathrm{mol} \text { of CNS } \\
\text { formed/mg of } \\
\text { protein) }\end{array}$ & $\begin{array}{c}\text { Source of } \\
\text { culture }\end{array}$ \\
\hline
\end{tabular}

Bacillaceae

Bacillus megaterium

Bacillus subtilis

800

1,800

Micrococcaceae

Staphylococcus aureus ATCC 25923

Staphylococcus epidermidis

Micrococcus luteus

Streptococcaceae

Group B, beta-hemolytic streptococcus

Group D, streptococcus

Pseudomonadaceae

Pseudomonas aeruginosa ATCC 17933

Pseudomonas aeruginosa ATCC 17934

Pseudomonas aeruginosa ATCC 19660

Pseudomonas fluorescens

Pseudomonas maltophilia

Pseudomonas pseudoalcaligenes

Pseudomonas reptilovora

Pseudomonas stutzeri

Gram-negative aerobic rods of uncertain affiliation

Alcaligenes faecalis

Bordetella bronchiseptica

1,200

2,300

Gram-negative facultatively anaerobic rods of uncertain affiliation Chromobacterium violaceum

Yersinia enterocolitica

\section{Neisseriaceae}

Acinetobacter calcoaceticus subsp. anitratum

Acinetobacter calcoaceticus subsp. anitratum strain 1-71

Acinetobacter calcoaceticus subsp. anitratum strain 1-77

Acinetobacter calcoaceticus subsp. anitratum strain a-83

Acinetobacter calcoaceticus subsp. anitratum strain 1-101

Acinetobacter calcoaceticus subsp. anitratum strain A

Acinetobacter calcoaceticus subsp. anitratum strain B

Acinetobacter calcoaceticus subsp. anitratum strain C

Acinetobacter calcoaceticus subsp. anitratum strain D

Acinetobacter calcoaceticus subsp. anitratum strain $\mathbf{E}$

Acinetobacter calcoaceticus subsp. anitratum strain F

Acinetobacter calcoaceticus subsp. anitratum strain G

Acinetobacter calcoaceticus subsp. anitratum strain $\mathrm{H}$

Acinetobacter calcoaceticus subsp. anitratum strain I

Acinetobacter calcoaceticus subsp. antitratum strain 1-104

Acinetobacter calcoaceticus subsp. lwoffi

Acinetobacter calcoaceticus subsp. lwoffi

Acinetobacter calcoaceticus subsp. lwoffi

\section{Clinical isolate}

Clinical isolate

ATCC

ATCC

Clinical isolate

Clinical isolate

Clinical isolate

Clinical isolate

Clinical isolate

\section{Enterobacteriaceae}

Escherichia coli

\section{Clinical isolate}

Shigella boydii
Clinical isolate Clinical isolate

U. of Michigan

U. of Michigan

U. of Michigan

$\mathrm{U}$. of Michigan

U. of Michigan

U. of Michigan

U. of Michigan

U. of Michigan

U. of Michigan

U. of Michigan

$\mathrm{U}$. of Michigan

$\mathrm{U}$. of Michigan

U. of Michigan

U. of Michigan

U. of Michigan

Clinical isolate

Clinical isolate

Clinical isolate

Clinical isolate

Clinical isolate

Clinical isolate
Clinical isolate 
TABLE 1. (continued)

\begin{tabular}{|c|c|c|}
\hline Organism & $\begin{array}{c}\text { Sp. act. } \\
\text { ( } \mu \mathrm{mol} \text { of CNS } \\
\text { formed } / \mathrm{mg} \text { of } \\
\text { protein) }\end{array}$ & $\begin{array}{l}\text { Source of } \\
\text { culture }\end{array}$ \\
\hline Edwardsiella tarda & 400 & Clinical isolate \\
\hline Citrobacter freundii & 300 & Clinical isolate \\
\hline Salmonella enteritidis & 0 & Clinical isolate \\
\hline Salmonella arizonae & 0 & Clinical isolate \\
\hline Klebsiella pneumoniae & 0 & Clinical isolate \\
\hline Klebsiella ozaenae & 0 & Clinical isolate \\
\hline Enterobacter aerogenes & 0 & Clinical isolate \\
\hline Enterobacter cloacae & 0 & Clinical isolate \\
\hline Enterobacter hafniae & 0 & Clinical isolate \\
\hline Serratia liquefaciens & 0 & Clinical isolate \\
\hline Serratia marcescens & 0 & Clinical isolate \\
\hline Serratia rubidae & 0 & Clinical isolate \\
\hline Proteus mirabilis & 0 & Clinical isolate \\
\hline Proteus morganii & 0 & Clinical isolate \\
\hline Proteus vulgaris & 0 & Clinical isolate \\
\hline Proteus rettgeri & 0 & Clinical isolate \\
\hline Proteus inconstans & 0 & Clinical isolate \\
\hline Proteus alcalifaciens & 0 & Clinical isolate \\
\hline
\end{tabular}

a Mechanical disruption by the French Press. Abbreviations: ATCC, American Type Culture Collection, Rockville, Md.; CNS, thiocyanate.

ascertain the lytic effectiveness of the lysozymeEDTA mixture.

Enzyme assay conditions. The assay for rhodanese was based on the method of Sörbo (8). The reaction mixture contained $1 \mathrm{ml}$ of $0.125 \mathrm{M}$ sodium thiosulfate, $0.5 \mathrm{ml}$ of $0.25 \mathrm{M}$ potassium cyanide, and $0.5 \mathrm{ml}$ of 0.1 tris(hydroxymethyl)aminomethane-hydrochloride buffer $(\mathrm{pH} \mathrm{8.0)}$. Added to this reaction mixture was $1.5 \mathrm{ml}$ of the lysed cell mixture or $0.5 \mathrm{ml}$ of the French cell-prepared extracts. The reaction mixture was incubated at $37^{\circ} \mathrm{C}$ for $5 \mathrm{~min}$, and the reaction was stopped with the addition of $0.5 \mathrm{ml}$ of $38 \%$ formaldehyde. The production of thiocyanate was determined colorimetrically by the addition of $2.5 \mathrm{ml}$ of $1 \%$ ferric nitrate (in $13 \%$ nitric acid) reagent, followed by centrifugation at $20,000 \times g$ for $5 \mathrm{~min}$ and measurement of absorbance at $460 \mathrm{~nm}$. One rhodanese unit was defined as that amount of enzyme which formed $1 \mu \mathrm{mol}$ of thiocyanate during the 5-min incubation period. The reaction was linear with time during the 5-min incubation period. Enzyme-free controls containing all of the above mentioned reagents never exhibited spontaneous production of thiocyanate.

For the study employing mechanically disrupted cells, the supernatants were assayed three times to determine the validity of the results. For a given culture to be considered positive for rhodanese activity, its cell-free extracts had to form a ferric nitratethiocyanate complex giving a minimum absorbance reading of 0.1 or greater at $460 \mathrm{~nm}$.

Protein determination. In the cell-free extract survey, protein determinations were based on the pro- cedure of Koch and Putnam (3) with crystalline bovine serum albumin used as the standard.

\section{RESULTS}

Initial studies on Acinetobacter and $P$. aeruginosa strains indicated that rhodanese activity was constitutively present regardless of the growth medium employed and was associated with the intracellular soluble fraction of the cell. Activity could never be detected extracellullarly in the broth after growth or in resting cells. Therefore, subsequent rhodanese assays were performed on cell-free extracts prepared from disrupted cultures. Table 1 itemizes the rhodanese activity in the cell-free extracts of 61 different strains of bacteria grown on peptoneTrypticase soy broth and mechanically disrupted. The greatest activity was detected in the two Acinetobacter species followed by Bordetella bronchiseptica. All strains of Pseudomonas, Shigella, Escherichia, and Citrobacter demonstrated less activity. However, no activity was detected in the cell-free extracts of the grampositive cocci or in the Serratia, Enterobacter, Klebsiella, Salmonella, and Proteus species.

Table 2 itemizes rhodenese activity in the lysed cells of several hundred Enterobacteriaceae strains. In this survey, only the Escherichia, Shigella, and Citrobacter species dem- 
TABLE 2. Intracellular rhodanese activity of lysozyme-EDTA-lysed cells of various bacteria

\begin{tabular}{|c|c|c|c|}
\hline Organism & $\begin{array}{c}\text { No. of } \\
\text { strains } \\
\text { examined }\end{array}$ & $\begin{array}{l}\text { Rhodanese } \\
\text { reaction }\end{array}$ & $\begin{array}{l}\text { Source of } \\
\text { culture }\end{array}$ \\
\hline \multicolumn{4}{|l|}{ Enterobacteriaceae } \\
\hline Escherichia coli ATCC 25922 & 1 & + & ATCC \\
\hline Escherichia coli ATCC 19413 & 1 & + & ATCC \\
\hline Escherichia coli & 130 & + & Clinical isolates \\
\hline Shigella boydii & 15 & + & Clinical isolates \\
\hline Shigella dysenteriae & 3 & + & Clinical isolates \\
\hline Shigella dysenteriae ATCC 13313 & 1 & + & ATCC \\
\hline Shigella flexneri & 8 & + & Clinical isolates \\
\hline Shigella sonnei & 10 & + & Clinical isolates \\
\hline Citrobacter diversus ATCC $27156^{a}$ & 1 & + & ATCC \\
\hline Citrobacter diversus & 2 & + & Clinical isolates \\
\hline Cirtobacter freundii & 7 & + & Clinical isolates \\
\hline Arizona hinshawii & 1 & - & Clinical isolates \\
\hline Salmonella typhi ATCC $19430^{\prime \prime}$ & 1 & - & ATCC \\
\hline Salmonella enteritidis ATCC 13076 & 1 & - & ATCC \\
\hline Salmonella enteritidis & 2 & - & Clinical isolates \\
\hline Salmonella typhimurium ATCC 14028 & 1 & - & ATCC \\
\hline Salmonella typhimurium & 14 & - & Clinical isolates \\
\hline Salmonella choleraesuis ATCC $13312^{n}$ & 1 & - & ATCC \\
\hline Klebsiella pneumoniae ATCC $13883^{a}$ & 1 & - & ATCC \\
\hline Klebsiella pneumoniae & 45 & - & Clinical isolates \\
\hline Klebsiella oxaenae & 5 & - & Clinical isolates \\
\hline Enterobacter aerogenes & 21 & - & Clinical isolates \\
\hline Enterobacter cloacae ATCC 23355 & 1 & - & ATCC \\
\hline Enterobacter cloacae ATCC 13047 & 1 & - & ATCC \\
\hline Enterobacter hafniae & 4 & - & Clinical isolates \\
\hline Enterobacter agglomerans & 5 & - & Clinical isolates \\
\hline Serratia marcescens ATCC 8100 & 1 & - & ATCC \\
\hline Serratia marcescens & 8 & - & Clinical isolates \\
\hline Proteus mirabilis & 30 & - & Clinical isolates \\
\hline Proteus morganii ATCC $25830^{a}$ & 1 & - & ATCC \\
\hline Proteus rettgeri ATCC 9250 & 1 & - & ATCC \\
\hline Proteus rettgeri & 2 & - & Clinical isolates \\
\hline Proteus vulgaris ATCC $13315^{a}$ & 1 & - & ATCC \\
\hline Proteus vulgaris & 5 & - & Clinical isolates \\
\hline Proteus inconstans ATCC 25825 & 1 & - & ATCC \\
\hline Proteus inconstans & 3 & - & Clinical isolates \\
\hline \multicolumn{4}{|l|}{ Neisseriaceae } \\
\hline Acinetobacter calcoaceticus ATCC 15308 & 1 & + & ATCC \\
\hline Acinetobacter calcoaceticus ATCC 17905 & 1 & + & ATCC \\
\hline Acinetobacter calcoaceticus ATCC 9957 & 1 & + & ATCC \\
\hline Acinetobacter calcoaceticus ATCC 15150 & 1 & + & ATCC \\
\hline Acinetobacter calcoaceticus & 20 & + & Clinical isolates \\
\hline Moraxella bovis ATCC 19575 & 1 & + & ATCC \\
\hline Moraxella lacunata & 1 & + & Clinical isolates \\
\hline \multicolumn{4}{|l|}{ Spirillaceae } \\
\hline Campylobacter fetus ATCC 29428 & 1 & - & ATCC \\
\hline Pseudomonadaceae & & & \\
\hline Pseudomonas aeruginosa ATCC $10145^{a}$ & 1 & + & ATCC \\
\hline
\end{tabular}


TABLE 2. (continued)

\begin{tabular}{|c|c|c|c|}
\hline Organism & $\begin{array}{c}\text { No. of } \\
\text { Strains } \\
\text { examined }\end{array}$ & $\begin{array}{l}\text { Rhodanese } \\
\text { reaction }\end{array}$ & $\begin{array}{l}\text { Source of } \\
\text { culture }\end{array}$ \\
\hline Pseudomonas aeruginosa ATCC 17933 & 1 & + & ATCC \\
\hline Pseudomonas aeruginosa ATCC 17934 & 1 & + & ATCC \\
\hline Pseudomonas aeruginosa ATCC 19660 & 1 & + & ATCC \\
\hline Pseudomonas aeruginosa & 26 & + & Clinical isolates \\
\hline Pseudomonas fluorescens ATCC 15553 & 1 & + & ATCC \\
\hline \multicolumn{4}{|l|}{ Vibrionaceae } \\
\hline Aeromonas hydrophila & 2 & - & Clinical isolates \\
\hline \multicolumn{4}{|l|}{ Rods of uncertain affiliation } \\
\hline Alcaligenes species & 5 & + & Clinical isolates \\
\hline \multicolumn{4}{|l|}{ Bacillaceae } \\
\hline Bacillus subtilis & 1 & + & Clinical isolate \\
\hline \multicolumn{4}{|l|}{ Streptococcaceae } \\
\hline Group A streptococcus & 1 & - & ATCC \\
\hline Group B streptococcus & 1 & - & Clinical isolate \\
\hline Group C streptococcus & 1 & - & ATCC \\
\hline Group D streptococcus & 1 & - & Clinical isolate \\
\hline Group F streptococcus & 1 & - & Clinical isolate \\
\hline Group G streptococcus & 1 & - & ATCC \\
\hline
\end{tabular}

${ }^{a}$ Type or neotype strain. Abbreviation: ATCC, American Type Culture Collection, Rockville, Md. Symbols: + , Rhodanese produced; - , rhodanese not produced.

onstrated rhodanese activity. No rhodanese activity was detected in the Salmonella, Klebsiella, Enterobacter, Serratia, and Proteus species. Also, the greatest activity was again associated with the Acinetobacter and $P$. aeruginosa strains.

\section{DISCUSSION}

The results described here suggest that intracellular rhodanese activity is found in a relatively large number of bacteria and can be detected rapidly and accurately by use of the EDTA-lysozyme cell lysis method. This procedure avoids the cumbersome and prolonged procedure of growing large numbers of cells and mechanically disrupting them after centrifugation. A number of functions have been associated with rhodanese. These functions include the role of cyanide detoxification (8), thiosulfate reductase activity (10), and a synthetic function involved in the formation of cysteine from sulfite (9). The presence or absence of rhodanese activity is a stable property which may have potential in differentiating the various genera of the family Enterobacteriaceae as well as other unrelated genera. At present, the Enterobacteriaceae can be divided into cyanide-sensitive and cyanideresistant groups of bacteria, a division based mainly on the work of Møller (5). The cyanidesensitive strains include Escherichia, Shigella,
Edwardsiella, Salmonella, and Arizona species. The cyanide-resistant strains include Citrobacter, Klebsiella, Enterobacter, Serratia, Proteus, Providencia, and Aeromonas species. Hence, our data seem to suggest a role for rhodanese other than cyanide detoxification based on the observation that it occurs in both cyanide-sensitive and cyanide-resistant members of the family Enterobacteriaceae. The presence or absence of activity in all members of a given genus so far examined suggests that this enzyme is a stable, heritable property which is not easily lost or promiscuously transferred from genus to genus and may be of value in future taxonomic studies as well as in diagnostic laboratories.

\section{ACKNOWLEDGMENTS}

We thank the following for their gracious gift of the bacterial cultures used in this study: Roger Bawdon, Detroit General Hospital; William Brown, Hutzel Hospital; Elliot Juni, University of Michigan; William LeBar, Bon Secours Hospital; Thomas Neblett, Henry Ford Hospital; and Chet Hornbeck, State of Michigan Department of Health.

\section{REPRINT REQUESTS}

Address reprint requests to: Dr. Richard S. Berk, Department of Microbiology and Immunology, Wayne State University School of Medicine, Detroit, MI 48201.

\section{IITERATURE CITED}

1. Hall, M. R., and R. S. Berk. 1968. Microbial growth on mercaptosuccinic acid. Can. J. Microbiol. 14:515-523.

2. Kaback, H. R. 1971. Bacterial membranes. Methods Enzymol. 22:99-120. 
3. Koch, A. L., and S. L. Putnam. 1971. Sensitive biuret method for determination of protein in an impure system such as whole bacteria. Anal. Biochem. 44:239245.

4. Lang, K. 1933. Die Rhodanbildung in Tierkorper. Biochem. Z. 259:243-256.

5. Møller, V. 1954. Diagnostic use of the Braun KCN test within the enterobacteriaceae. Acta Pathol. Microbiol. Scand. 34:115-126.

6. Schook, L. B., and R. S. Berk. 1978. Nutritional studies with Pseudomonas aeruginosa grown on inorganic sulfur sources. J. Bacteriol. 133:1377-1382.
7. Sörbo, B. H. 1953. Crystalline rhodanese. Acta Chem. Scand. 7:1129-1136.

8. Sörbo, B. H. 1960. Rhodanese. Enzymology. 2:334-337.

9. Torü, K., and R. S. Bandurski. 1967. Yeast sulfatereducing system. Biochim. Biophys. Acta 136:286-295.

10. Villarejo, M., and J. Westley. 1963. Rhodanese-catalyzed reduction of thiosulfate by reduced lipoic acid. J. Biol. Chem. 238: 1185-1186.

11. Yoch, D. C., and E. S. Lindstrom. 1971. Survey of photosynthetic bacteria for rhodanese (thiosulfate: cyanide sulfur transferase) activity. J. Bacteriol. 106: 700701. 